\title{
Variation in ovarian morphology in four species of New World moles with a peniform clitoris
}

\author{
N. M. Rubenstein ${ }^{1}$, G. R. Cunha ${ }^{2}$, Y. Z. Wang ${ }^{2}$, K. L. Campbell ${ }^{3}$, A. J. Conley ${ }^{4}$, \\ K. C. Catania ${ }^{5}$, S. E. Glickman ${ }^{1,6}$ and N. J. Place ${ }^{1 *}$ \\ ${ }^{1}$ Departments of Psychology and ${ }^{6}$ Integrative Biology, University of California, Berkeley, CA 94720, USA; \\ ${ }^{2}$ Department of Anatomy, University of California, San Francisco, CA 94143, USA; ${ }^{3}$ Department of \\ Zoology, University of Manitoba, Winnipeg, Manitoba R3T 2N2, Canada; ${ }^{4}$ Department of Population \\ Health and Reproduction, University of California, Davis, CA 995616, USA; and ${ }^{5}$ Department of \\ Biological Sciences, Vanderbilt University, Nashville, TN 37235, USA
}

\begin{abstract}
Female moles of the Old World genus Talpa display a curious suite of reproductive features that include a peniform clitoris and ovaries with a discrete interstitial gland or testis-like region (so-called 'ovotestes'). The masculinization of the female external genitalia in Talpa has accordingly been linked with secretion of androgens from the interstitial gland region of the fetal gonad. Although their ovarian morphology has received less attention, some species of New World moles also have ovaries with a pronounced interstitial gland (for example star-nosed mole, Condylura cristata), whereas females of other species do not (for example eastern mole, Scalopus aquaticus). Although it is difficult to determine the sex of both Old and New World moles, published accounts describing the external genitalia of female moles are available only for Talpa. The hypothesis that masculinization of the
\end{abstract}

female external genitalia in moles is associated with the presence of an ovarian interstitial gland (OIG) was tested in the present study by using a comparative approach to determine whether these features are ever found in isolation of one another. Three genera of North American moles (Scapanus, Condylura and Neurotrichus) were studied and a peniform clitoris was found in all three species, but OIG were found in only two of three genera. The ovaries of $S$. latimanus and $S$. orarius were unremarkable, with no evidence of a discrete interstitial gland or testis-like region. Mapping these results onto recent talpid phylogenies indicates that loss of the bipolar ovarian morphology is a derived trait in Scapanus, and conclusively demonstrates that masculinization of the external genitalia in female moles can develop in the presence or absence of 'ovotestes'.

\section{Introduction}

Differentiation of the external genitalia in eutherian mammals along male or female lines is generally dependent upon whether the gonads differentiate into ovaries or testes (Jost, 1953; Wilson et al., 1981). If the gonads differentiate into testes, male-pattern development ensues as a result of testosterone secretion by the fetal or neonatal testes and its conversion to the more potent androgen, $5 \alpha$-dihydrotestosterone (DHT), within target tissues (Wilson et al., 1981). Exposure to testosterone or DHT is associated with differentiation of the genital tubercle into an elongated phallus traversed to its tip by the urethra, that is a penis, and the differentiation and fusion of the urogenital folds into a scrotum. In the absence of androgen stimulation, as in normal females or in males with androgen insensitivity

*Correspondence

Email: ned@socrates.Berkeley.EDU (for example testicular feminization syndrome), a clitoris and a separate urethra forms and the urogenital folds remain apart to form labial structures that border the vaginal opening.

However, in several species of mammal, the external genitalia of all females are masculinized to some extent, typically evident by an elongation of the clitoris, which may or may not be traversed by the urethra. This anatomical feature is found in a diverse group of mammals, covering several orders (Carnivora: Matthews, 1939; Cunha et al., 2003; Primates: Hill, 1958; Insectivora: Matthews, 1935). The spotted hyaena (Carnivora, Crocuta crocuta) represents the most extreme case. Female spotted hyaenas have a penis-like clitoris and a pseudo-scrotum; they lack an external vaginal opening, and thus void, copulate, and give birth through the single urogenital canal of the clitoris (Matthews, 1939; Davis and Story, 1949; Neaves et al., 1980; Frank et al., 1990). Several years before Matthews (1939) carefully illustrated the reproductive anatomy and histology of the 

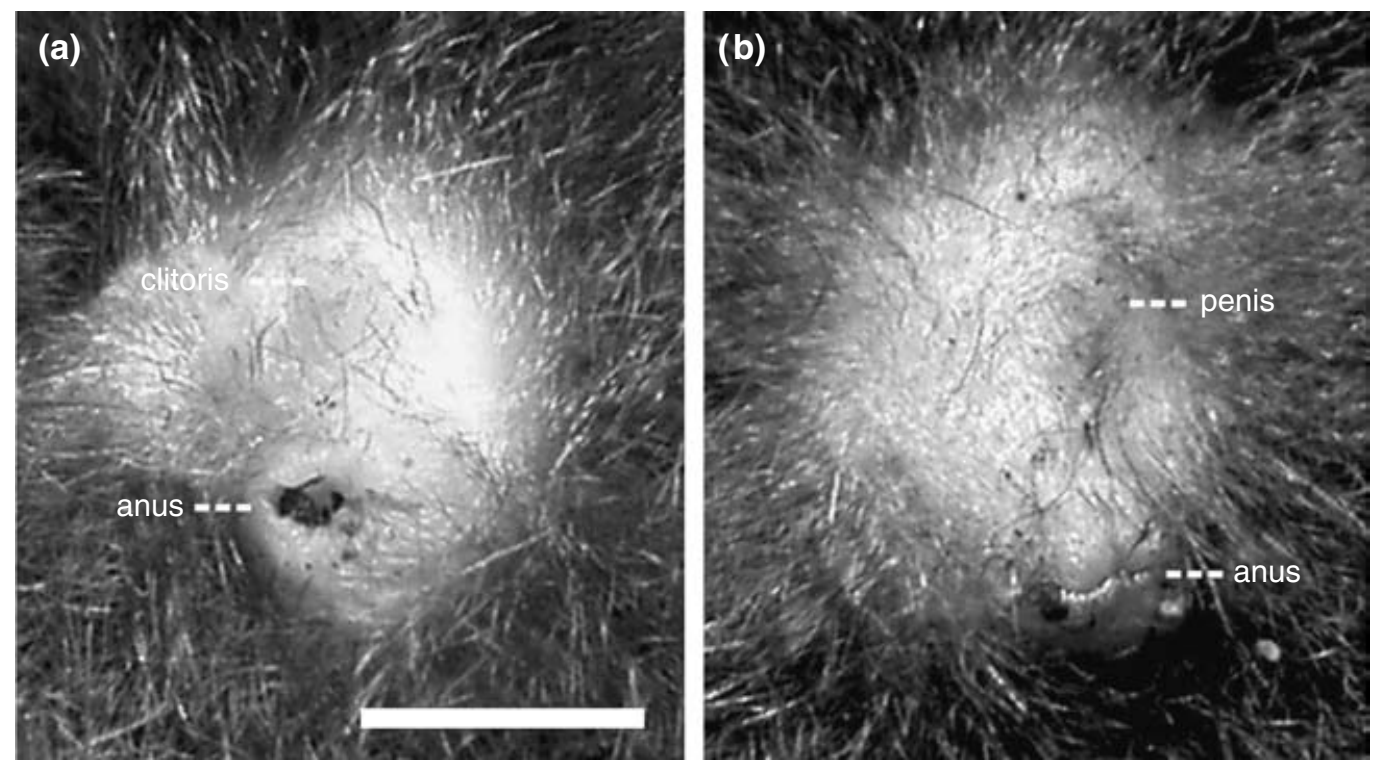

Fig. 1. External genitalia of adult (a) female and (b) male Scapanus latimanus captured during the nonbreeding season. The vaginal introitus is closed and mean anogential distance is not sexually dimorphic (see Fig. 5a). Scale bar represents $3 \mathrm{~mm}$.

spotted hyaena, he described the 'intersexuality' of the common European mole (Insectivora, Talpa europaea) (Matthews, 1935). It can be difficult to determine the sex of individuals of this, and other species of Talpa, especially outside of the breeding season when the vaginal opening is completely closed (Gorman and Stone, 1990). The clitoris of female European moles is very similar to the penis of the male, and the vaginal introitus is closed until sexual maturity. After puberty the introitus opens on a seasonal basis to permit copulation and parturition, and closes thereafter (Matthews, 1935).

In addition to a peniform clitoris, female moles of the genus Talpa have been reported to have 'ovotestes' (Matthews, 1935; Deanesly, 1966). The gonads of female Talpa have two distinct poles, one containing follicles, and the other containing a testis-like region with interstitial tissue and interspersed medullary cords (Jiménez et al., 1993; Sanchez et al., 1996). As the ovarian interstitial gland (OIG) lacks spermatogenic function, the term 'ovaries' is used here to designate the female gonads, as suggested by Beolchini et al. (2000). The abnormal development of epididymides adjacent to the OIG indicated to Matthews (1935) that testosterone is secreted by the fetal ovary, and may provide a mechanism for masculinization of the external genitalia of the female.

Several species of North American moles, outside the genus Talpa, are also difficult to sex during the non-breeding season (L. N. Carraway, personal communication; Fig. 1). At least one of these species, the star-nosed mole (Condylura cristata), was reported by Mossman and Duke (1973) to have ovaries similar in structure to those of European moles. These findings were supported by photomicrographs that demonstrate the 'massive so-called interstitial gland' in Condylura. Whereas the ovarian architecture of Neurotrichus gibbsii is more conventional in overall appearance, the shrew mole ovaries were noted to have large groups of 'gonadal adrenal type interstitial gland tissue' (Mossman and Duke, 1973). Scalopus aquaticus (the eastern mole) and $S$. latimanus are the only species of Talpidae listed in Mossman and Duke (1973) as having ovaries devoid of any interstitial gland tissue. However, this absence of interstitial gland tissue in the ovaries of $S$. latimanus was equivocal, as Mossman and Duke stated that the supporting data were inadequate.

The present study investigated whether the presence of 'ovotestes' is required for the correlated appearance of a peniform clitoris in moles. Anatomical and histological studies were completed of the external genitalia and ovaries of two Scapanus species, the broad-footed ( $S$. latimanus) and coast moles ( $S$. orarius); specimens of the star-nosed (C. cristata) and shrew moles ( $N$. gibbsii) were also examined. Additionally, the present study investigated whether the presence of ovotestes or a peniform clitoris is associated with a reduction in other indices of sexual dimorphism in moles, for example penile or clitoral length, anogenital distance and body size. The authors felt that this comparative approach would prove useful in understanding whether the OIG plays a role in the masculinization of female moles. Finally, because the view of the phylogenetic relationship of Old and New World species of mole has varied depending on the method of investigation (Hutchinson, 1976; Yates and Moore, 1990; Whidden, 2000), the authors attempted to map these traits on to current mole phylogenies to determine whether the interspecific 
variation in ovarian and urogenital morphology favours one phylogeny over another.

\section{Materials and Methods}

\section{Animals}

Tissues from 26 broad-footed moles ( $S$. latimanus) were obtained locally from several sources: (1) Museum of Vertebrate Zoology, University of California, Berkeley; (2) commercial pest control specialists; and (3) after livecapture and euthanasia by one of the authors. The three other species of mole ( $S$. orarius, $C$. cristata and $N$. gibbsii) are not found in the San Francisco Bay area; thus smaller numbers of specimens were obtained from various investigators ( $n=4,1$ and 1 , respectively). All specimens were catalogued at the University of California, Berkeley, and analysed there or at the UCDavis and UC-San Francisco campuses. The sex of animals was determined by direct visualization of the internal reproductive organs.

\section{Biometry}

Body length, phallus length and anogenital distance were measured in 26 adult broad-footed moles ( 16 males and 10 females). Sample sizes were too small for analysis in the three other species. Body length was measured to the nearest $\mathrm{mm}$, from the tip of the nose to the end of the tail. Phallus length and anogenital distance were measured by a single investigator, who was unaware of the sex of the animal. Phallus length was measured from the base of the penis or clitoris to its tip with electronic calipers, which measured to within $0.01 \mathrm{~mm}$ (Mitutoyo America, Aurora, IL). Anogenital distance was measured from the ventral base of the phallus to the most proximal point of the anus.

\section{Tracing the course of the urethra}

Intact specimens of the two Scapanus species were used to determine whether the urethra traverses the clitoris, and if so, the location of the urethral meatus. Royal blue ink was slowly injected into the bladder and the anogenital region was visualized under a dissecting microscope. This procedure was carried out in two female and one male $S$. latimanus, and four female $S$. orarius. Serial sectioning and histological staining of the phallus from the proximal to distal end confirmed these findings. This histological approach was also applied to the Condylura and Neurotrichus specimens.

\section{Tissue harvest and procurement}

Gonads from 16 live-caught $S$. latimanus were removed and preserved in $4 \%$ paraformaldehyde at $4{ }^{\circ} \mathrm{C}$ overnight. Tissues were transferred to Dulbecco's phosphate-buffered saline (Gibco) for a time equal to that for fixation, then into graded ethanol from $30 \%$ to $70 \%$. Tissues in $70 \%$ ethanol were stored at room temperature until histological analysis. For all other animals, tissues were placed in $10 \%$ phosphate-buffered formalin before shipment. Fixation lasted for at least $48 \mathrm{~h}$, with subsequent transfer to phosphate-buffered saline and graded ethanol. Tissues in $70 \%$ ethanol were stored at room temperature until histological analysis.

\section{Histological procedures}

Tissues were prepared for microscopic examination by standard paraffin methods, serial sectioned at $8 \mu \mathrm{m}$, and stained with haematoxylin and eosin. Histological examination was completed on the gonads of 10 female and 16 male $S$. latimanus, four female $S$. orarius, one female $C$. cristata and one female N. gibbsii. In addition, coronal sections through the clitoris or penis of nine female and 10 male $S$. latimanus, one female $C$. cristata, and one female N. gibbsii were prepared and stained with haematoxylin and eosin.

\section{Statistical analysis}

Investigation of sex differences in body length, anogenital distance, and phallic length were made using the non-parametric Mann-Whitney $U$ test. Differences at $P<0.05$ were considered significant.

\section{Results}

\section{Ovarian histology}

Ovaries from $S$. latimanus showed numerous follicles at various stages of development throughout the ovary (Fig. 2a,b). No polarity could be detected when ovaries were serially sectioned, and the $S$. latimanus ovaries showed no signs of a discrete interstitial gland, or medullary cords. This held true whether the ovaries were taken from animals during the breeding season (December-April) or the non-breeding season (MayNovember). Histological sections of $S$. orarius ovaries exhibited some autolysis and were of lower quality; however, the ovarian architecture appeared similar to that of $S$. latimanus (data not shown). The ovarian histology of the star-nosed and shrew moles matched the descriptions and photomicrographs found in Mossman and Duke (1973). In both species the ovary is highly polar, with follicles clustered in one pole and an interstitial gland region found in the other (Fig. 2c,f). Medullary cords are found dispersed throughout the interstitial gland region of the star-nosed mole (Fig. 2g, h). The shrew-mole ovary is relatively less polar than that of the star-nosed mole; in some sections, follicles were found in the thin cortical layer that surrounds the ovary (Fig. 2e). 

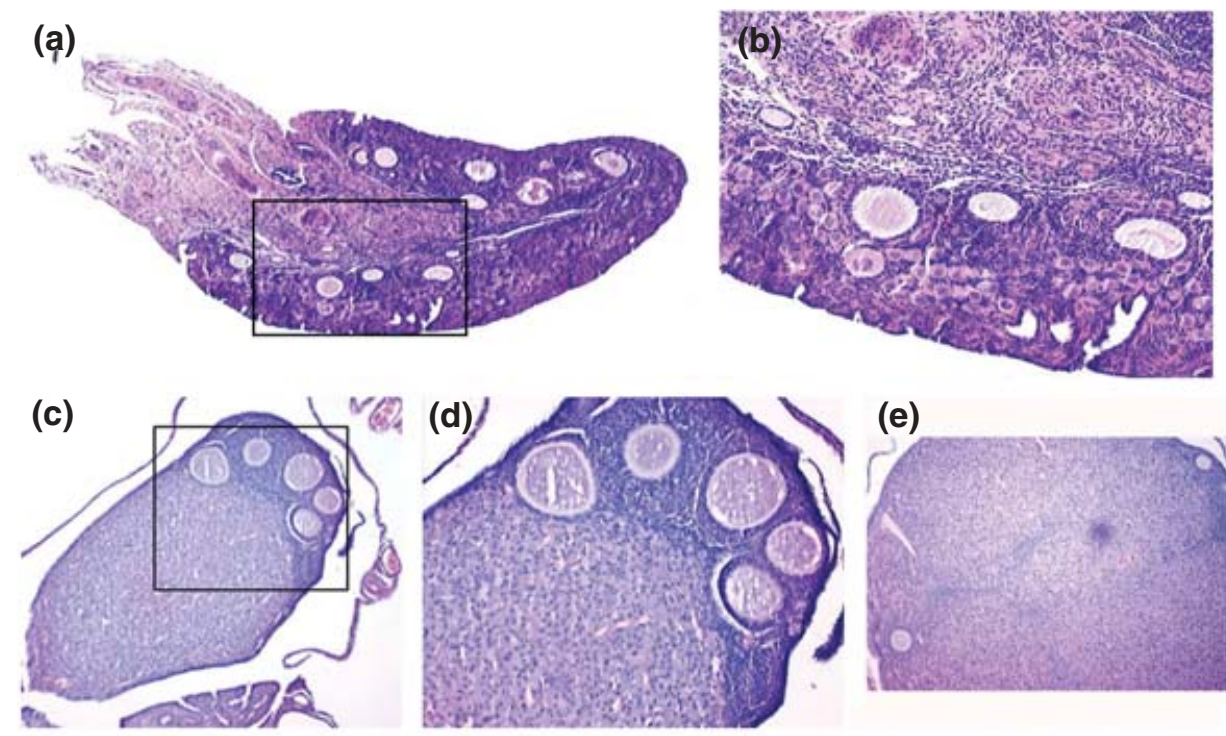

(e)
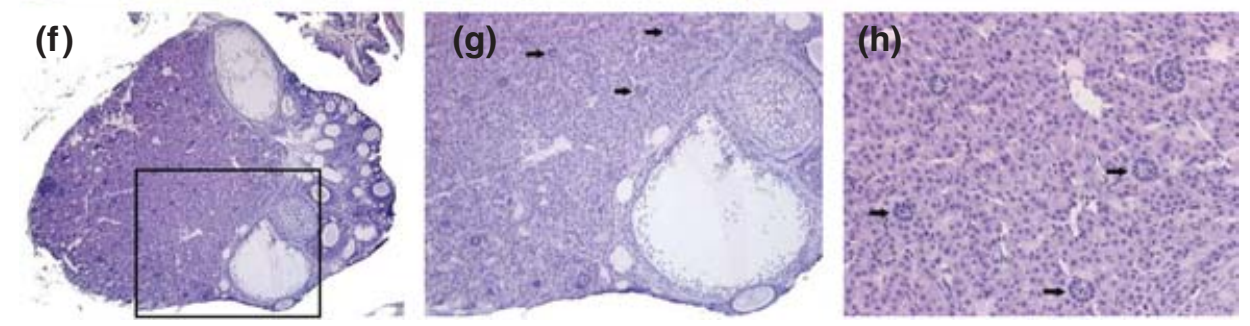

Fig. 2. Sections through the ovaries of $(\mathrm{a}, \mathrm{b})$ the broad-footed mole (Scapanus latimanus), (c-e) the shrew mole (Neurotrichus gibbsii) and $(\mathrm{f}-\mathrm{h})$ the star-nosed mole (Condylura cristata). Crosssectional views of whole ovaries $(\mathrm{a}, \mathrm{c}, \mathrm{f})$ photographed at $\times 40$ magnification; the outlined area in each of these views is displayed at higher magnification $(\times 100)$ in the adjacent frame $(b, d$ and $g$, respectively). Follicles at various stages of development are found widely disseminated throughout the ovary of $S$. latimanus, with the mesovarium to the left (a). Follicle distribution is more limited in the ovaries from Neurotrichus and Condylura $(\mathrm{c}, \mathrm{f})$. The ovaries of the last two species also show a discrete interstitial gland region $(d, g)$. In an alternate view of the Neurotrichus ovary, follicles can be seen on opposite sides of the interstitial gland within the thin cortical layer (e). Higher magnification $(\times 200)$ of the Condylura ovary reveals discrete medullary cords within the interstitial gland (arrows in $\mathrm{g}, \mathrm{h}$ ).

\section{Clitoral anatomy and histology}

In all four species of mole examined, females demonstrated a prominent phallus with the urethra exiting at or near the tip. Injection of dye into the bladder of male and female broad-footed moles and female coast moles confirmed that both the penis and clitoris are traversed by the urethra. These findings were further corroborated histologically by the serial transverse sections of the penis and clitoris in S. latimanus (Fig. 3a,b). In both sexes the phallus contains erectile bodies proximally, and is surrounded by a hair-bearing prepuce. The urethra is found in the midline just beneath the corporal bodies. In the mid-region of the phallus a central core of tissue, possibly the glans, overlies the urethra. A similar histological appearance was seen in the midregion of the clitoris in the star-nosed mole (Fig. 4a). In the most distal sections taken from the Scapanus specimens (Fig. $3 a, b)$, a ventral opening or slit was found in the prepuce of both the penis and clitoris. The histology of the shrew-mole clitoris was incomplete, as the clitoris may have been sectioned too distally to capture a view of the glans clitoris or erectile bodies, but the traversing urethra can be seen (Fig. 4b).

\section{Biometry}

In the broad-footed mole, phallus length and anogenital distance of female $S$. latimanus were not significantly different from those of males (Fig. 5a). Mean body length was significantly greater in males $(165 \pm 2 \mathrm{~mm})$ than females (158 $\pm 2 \mathrm{~mm}$ ), but there is considerable overlap, rendering body length an unreliable indicator of sex (Fig. 5b). Mean tail length was nearly identical in males $(31 \pm 3 \mathrm{~mm})$ and females $(30 \pm 2 \mathrm{~mm})$ and did not contribute to the sex differences in overall body length. 

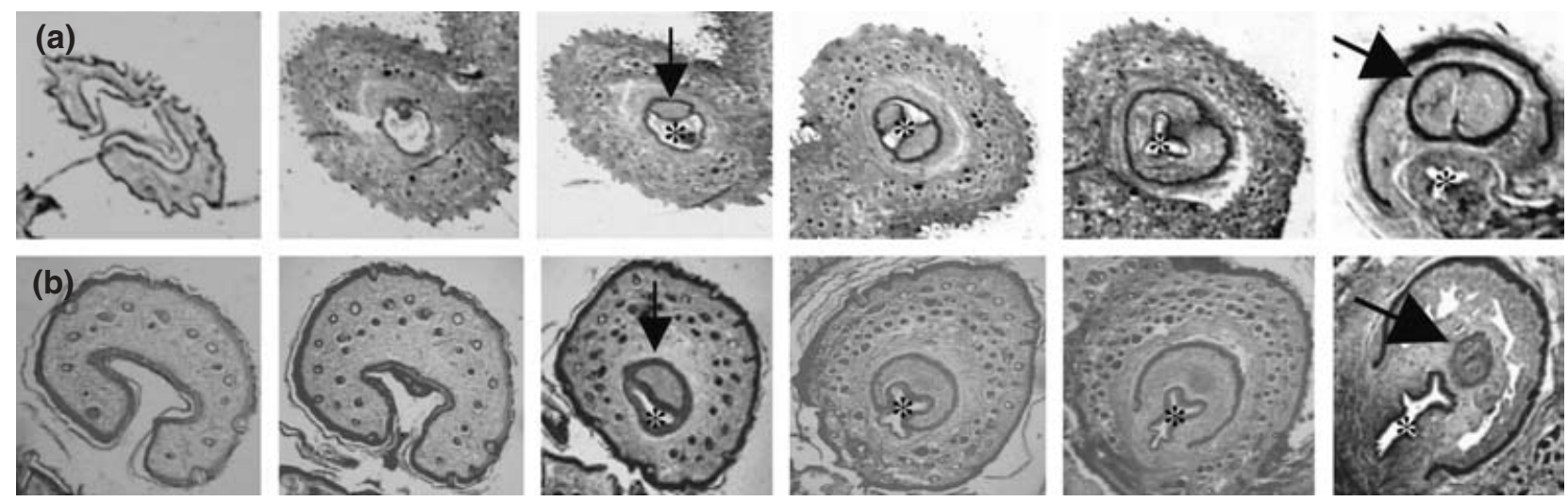

Fig. 3. Serial transverse sections $(\times 25)$ of $(a)$ the penis and $(b)$ the clitoris of the broad-footed mole (Scapanus latimanus). Sections are distal to proximal from left to right. The urethra $\left(^{*}\right)$ can be seen in the proximal and mid-sections. The most distal sections (left-most frames) contain only prepuce. A central core of tissue, possibly the glans (small arrows) is seen in the mid-sections, and the corporal bodies (larger arrows) are found in proximal sections.
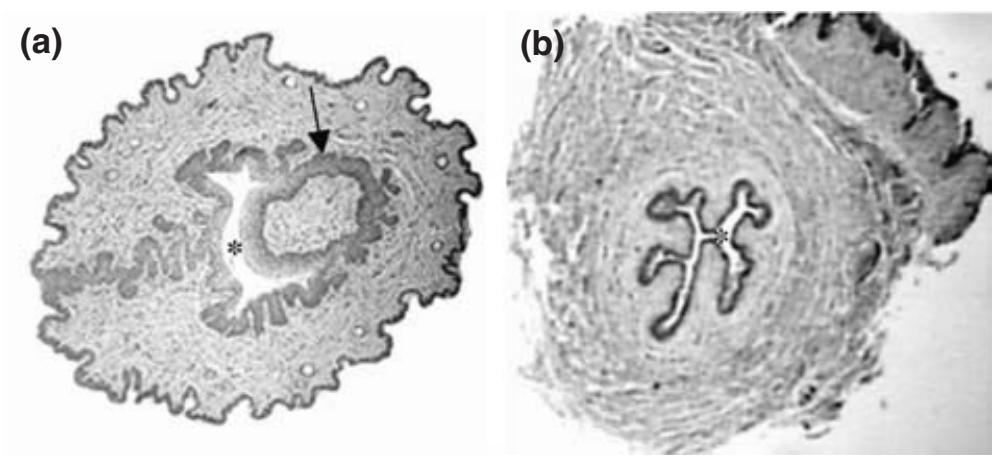

Fig. 4. Transverse sections through the clitoris of (a) the star-nosed mole (Condylura cristata) and (b) the shrew mole (Neurotrichus gibbsii). The urethra $\left({ }^{*}\right)$ is centrally located, and a central core of tissue, possibly the glans (arrow) can be seen overlying it in the Condylura specimen, but not in the Neurotrichus specimen. The Neurotrichus specimen may have been sectioned too distally to visualize either the glans or corporal bodies in this species.

Table 1. Summary of ovarian and external genitalia characteristics in four genera of moles

\begin{tabular}{lllll}
\hline & Scapanus spp. & Condy/ura cristata & Neurotrichus gibbsii & \multicolumn{1}{c}{ Talpa spp. } \\
\hline Female gonad & Follicular ovary & Ovary/interstitial gland & Ovary/interstitial gland & Ovary/interstitial gland \\
Medullary cords & None & Yes & Few $^{\mathrm{a}}$ & Yes \\
Phallus & Penile clitoris & Penile clitoris & Penile clitoris $^{\mathrm{b}}$ & Penile clitoris \\
\hline
\end{tabular}

aNot seen in ovaries from present study, but described and illustrated by Mossman and Duke (1973).

breliminary assessment based on gross inspection and limited histology.

\section{Discussion}

In all species of talpid moles studied to date, females have been found to have a peniform clitoris. This masculinization of the female's external genitalia occurs in species with and without so-called 'ovotestes', as summarized in Table 1. Anogenital distance is sexually dimorphic in a species of mole with OIG ( $T$. europaea) (Gorman and Stone, 1990; Whitworth et al., 1999), but this sexual dimorphism is absent in a species lacking them ( $S$. latimanus; present study). Anogenital distance has been shown to be a sensitive biomarker of prenatal 
(a)

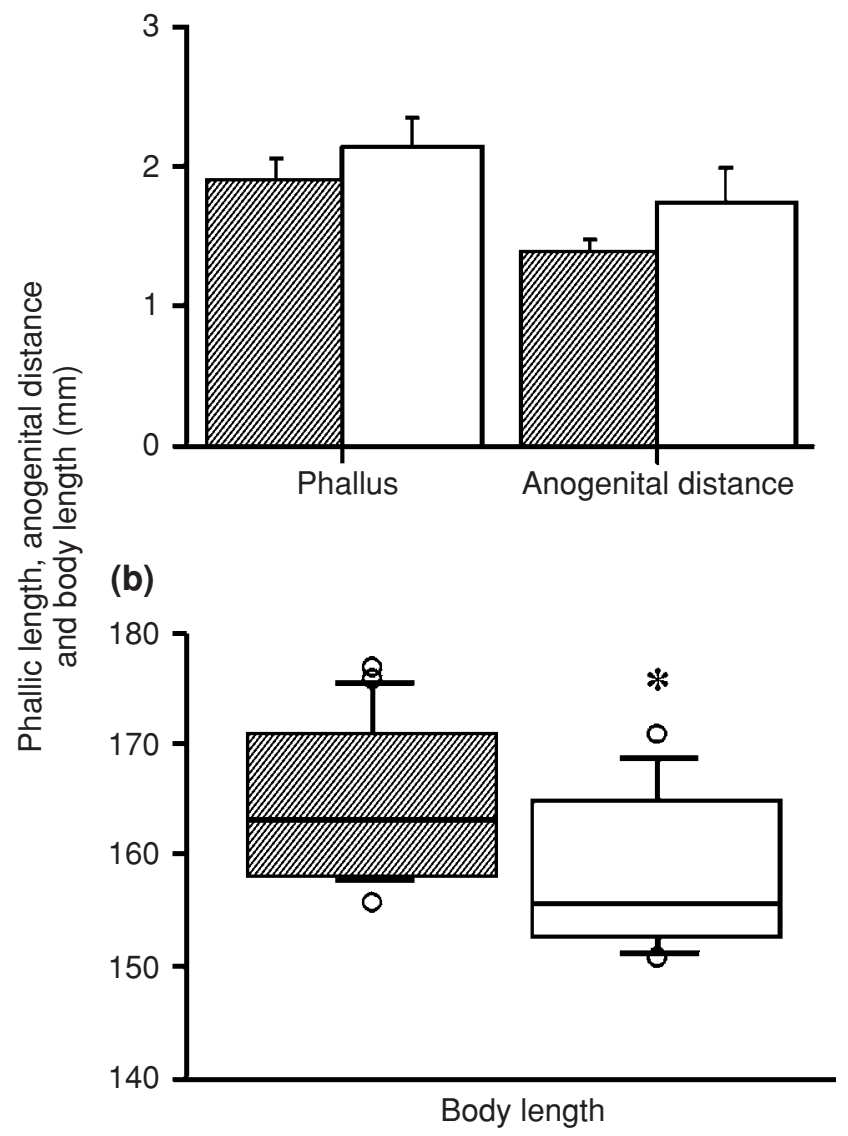

Fig. 5. (a) Mean ( \pm SEM) phallus length and anogenital distance in male $(\square ; n=16)$ and female $(\square ; n=10)$ broad-footed moles (Scapanus latimanus). (b) Box plot of body length in male ( $\nabla)$ and female $(\square)$ broad-footed moles. ${ }^{*}$ Mean body size in females is significantly less than in males $(P<0.05)$.

exposure to endogenous testosterone in female mice (vom Saal and Bronson, 1980), but this may or may not be true in moles. An alternative explanation for the presence or absence of a sexual dimorphism in anogenital distance may be related to body size. In European moles, males are generally larger than females (Gorman and Stone, 1990). Verts and Carraway (1998) suggested that male and female broad-footed moles are similar in body size and mass. However, on the basis of the limited sample size in the present study $(n=26)$, males were found to be significantly longer than females (Fig. 5b), even though considerable overlap was observed.

Mechanisms to explain the natural masculinization of female genitalia during sexual differentiation typically involve a search for an alternate source of testosterone. For example, in the spotted hyaena early studies indicated that the maternal ovary (Matthews, 1939) or the fetal ovary (Racey and Skinner, 1979; Lindeque and Skinner, 1982) might be the alternative source of androgens. Later studies demonstrated that the masculinization of female spotted hyaenas involves a two-step process, whereby androstenedione, a relatively weak androgen, is secreted from the maternal ovaries and is converted to testosterone by the placenta (Licht et al., 1992; Yalcinkaya et al., 1993; Licht et al., 1998).

The fetal ovary as a source of prenatal androgens may be a more tenable hypothesis in the case of the European mole. This is an attractive hypothesis given the presence of OIG and the abnormal development of epididymides in female fetuses of this species (Matthews, 1935). The presence of epididymides in females implies the production and action of testosterone at early stages of sexual differentiation. Conversely, masculinization of female broad-footed moles occurs in the absence of a distinct OIG. Of course the ovary of the broad-footed mole need not demonstrate an unusual histological architecture to secrete androgens. Ovarian theca cells synthesize androgens, providing substrate for conversion to oestrogens by follicular granulosa cells (Yeh and Adashi, 1999), and could produce sufficient concentrations of androgens to masculinize female offspring. The possibility of an androgen-independent mechanism to explain the masculinization of female moles should be entertained, as it has been in spotted hyaenas (Drea et al., 1998). However, Godet (1946) demonstrated that androgens must play some role in the differentiation of the external genitalia in T. europaea, as anogenital distance and phallic length of newborn males and females were rendered indistinguishable when pregnant dams were treated with testosterone propionate.

In an attempt to address when the bipolar ovary arose in the talpid lineage, the present authors mapped this trait onto recent mole phylogenies (Hutchinson, 1976; Yates and Moore, 1990; Whidden, 2000). For the four genera discussed in the present study, Talpa, Condylura, Neurotrichus and Scapanus, the results of the three phylogenetic analyses were in agreement that Scapanus was the most derived. Although there was no strict consensus regarding the phylogeny of the remaining three genera, Condylura appears to be the most basal talpid genus with Neurotrichus tending to exhibit a more intermediate position. Whidden (2000) stated that the fully fossorial moles are monophyletic on the basis of his comparative myology approach, and further stated that Talpa and Scapanus are 'sister taxon'. This places a species with bipolar ovaries in close phylogenetic proximity to a species with unremarkable ovaries that lack a discrete interstitial gland region. The eastern mole, Scalopus aquaticus, and Scapanus were consistently placed as a monophyletic pair (Hutchinson, 1976; Yates and Moore, 1990; Whidden, 2000), and Scalopus was also reported by Mossman and Duke (1973) as lacking a discrete OIG. Taken together, the absence of OIG in the most derived genera, Scapanus and Scalopus, and their presence in all other talpids studied to date, indicates that this is an ancestral trait in both Old and New World moles. 
The authors would like to thank I. Zucker and C. Drea for their translation of the Godet paper; S. Mapes, J. Vidal and D. Whitworth for their assistance with histology; J. Brody for help with figures; and the Museum of Vertebrate Zoology and J. Anderson (Critter Control, Concord, CA) for help in obtaining mole specimens. The comments of the Editorial Board Member and three anonymous referees greatly improved the manuscript. This study was supported by a National Research Service Award HD-08729 from the NICHD/NIH to $\mathrm{N}$. J. Place, by grant $\mathrm{MH}-39917$ from the $\mathrm{NIMH} / \mathrm{NIH}$ to $\mathrm{S}$. E. Glickman, and by a NSERC (Canada) discovery grant to K. L. Campbell.

\section{References}

Beolchini F, Rebecchi L, Capanna E and Bertolani R (2000) Female gonad of moles, genus Talpa (Insectivora, Mammalia): ovary or ovotestis? Journal of Experimental Zoology 286 745-754

Cunha GR, Wang Y, Place NJ, Lui W, Baskin L and Glickman SE (2003) The urogenital system of the female spotted hyena (Crocuta crocuta): a functional histological study Journal of Morphology 265 205-218

Davis DD and Story HE (1949) The female external genitalia of the spotted hyena Fieldiana. Zoology 31 277-283

Deanesly R (1966) Observations on reproduction in the mole Talpa europaea. In Comparative Biology of Reproduction in Mammals vol 15 pp 387-402 Ed IW Rowlands. Academic Press, London

Drea CM, Weldele ML, Forger NG, Coscia EM, Frank LG, Licht P and Glickman SE (1998) Androgens and masculinization of genitalia in the spotted hyaena (Crocuta crocuta). 2. Effects of prenatal anti-androgens Journal of Reproduction and Fertility 113 117-127

Frank LG, Glickman SE and Powch I (1990) Sexual dimorphism in the spotted hyaena (Crocuta crocuta). Journal of Zoology, London 221 308313

Godet R (1946) Biologie experimentale - modifications de l'organogense des voies urogénitales des embryons de taupes (Talpa europæa $\mathbf{L}$ ), par action du propionate de testostérone Comptes Rendus Hebdomadaires Des Seances De L Academie Des Sciences 222 1526-1527

Gorman ML and Stone RD (1990) The Natural History of Moles Comstock Publishing Associates, Ithaca

Hill WCO (1958) External genitalia Primatologia 3 630-704

Hutchinson JH (1976) The Talpidae (Insectivora, Mammalia): evolution, phylogeny and classification PhD Thesis, University of California, Berkeley

Jiménez R, Burgos M, Sanchez A, Sinclair AH, Alacron FJ, Marin JJ, Ortega E and Diaz de la Guardia R (1993) Fertile females of the mole Talpa occidentalis are phenotypic intersexes with ovotestes Development 118 1303-1311

Jost A (1953) Problems of fetal endocrinology: the gonadal and hypophyseal hormones Recent Progress in Hormone Research 8 379-418

Licht P, Frank LG, Pavgi Sc, Yalcinkaya TM, Siiteri PK and Glickman SE (1992) Hormonal correlates of 'masculinization' in female spotted hyaena (Crocuta crocuta). 2. Maternal and fetal steroids Journal of Reproduction and Fertility $95463-474$

Licht P, Hayes T, Tsai P, Cunha G, Kim H, Golbus M, Hayward S, Martin MC, Jaffe RB and Glickman SE (1998) Androgens and masculinization of genitalia in the spotted hyaena (Crocuta crocuta). 1. Urogenital morphology and placental androgen production during fetal life Journal of Reproduction and Fertility 113 105-116

Lindeque M and Skinner JD (1982) Fetal androgens and sexual mimicry in spotted hyaenas (Crocuta crocuta). Journal of Reproduction and Fertility 65 405-410

Matthews LH (1935) The oestrous cycle and intersexuality in the female mole (Talpa europaea Linn) Proceedings of the Zoological Society, London, Series 21935 347-383

Matthews LH (1939) Reproduction of the spotted hyaena (Crocuta crocuta Erxleben) Philosophical Transactions of the Royal Society, London, Series B 230 1-78

Mossman HW and Duke KL (1973) Comparative Morphology of the Mammalian Ovary University of Wisconsin Press, Madison

Neaves WB, Griffin JE and Wilson JD (1980) Sexual dimorphism of the phallus in spotted hyaena (Crocuta crocuta) Journal of Reproduction and Fertility 59 509-513

Racey PA and Skinner JD (1979) Endocrine aspects of sexual mimicry in spotted hyaenas Crocuta crocuta. Journal of Zoology, London 187315 326

Sanchez A, Bullejos M, Burgos M, Hera C, Stomatopoulos C, Diaz de la Guardia R and Jiménez R (1996) Females of four mole species of the genus Talpa (Insectivora, Mammalia) are true hermaphrodites with ovotestes Molecular Reproduction and Development 44 289-294

Verts BJ and Carraway LN (1998) Land Mammals of Oregon University of California Press, Berkeley

vom Saal FS and Bronson FH (1980) Sexual characteristics of adult female mice are correlated with their blood testosterone levels during prenatal development Science 208 597-599

Whidden HP (2000) Comparative myology of moles and the phylogeny of the Talpidae (Mammalia, Lipotyphla) American Museum Novitates 3294 $1-53$

Whitworth DJ, Licht P, Racey PA and Glickman SE (1999) Testis-like steroidogenesis in the ovotestis of the European mole, Talpa europaea. Biology of Reproduction 60 413-418

Wilson JD, George FW and Griffin JE (1981) The hormonal control of sexual development Science 211 1278-1284

Yalcinkaya TM, Siiteri PK, Vigne J-L, Licht P, Pavgi S, Frank LG and Glickman SE (1993) A mechanism for virilization of female spotted hyenas in utero. Science 260 1929-1931

Yates TL and Moore DW (1990) Speciation and evolution in the family Talpidae (Mammalia: Insectivora). In Evolution of Subterranean Mammals at the Organismal and Molecular Levels pp 1-22 Eds E Nevo and OA Reig. Alan R. Liss, New York

Yeh J and Adashi EY (1999) The ovarian life cycle. In Reproductive Endocrinology: Physiology, Pathophysiology and Clinical Management p. 170 Eds SSC Yen, RB Jaffe and RL Barbieri. WB Saunders Co., Philadelphia

Received 12 June 2003.

First decision 1 July 2003.

Revised manuscript received 3 July 2003.

Accepted 26 August 2003. 